\title{
Effects of MSM on exercise-induced muscle and joint pain: a pilot study
}

\author{
Eric D Withee*, Kimberly M Tippens, Regina Dehen, Douglas Hanes \\ From The Twelfth International Society of Sports Nutrition (ISSN) Conference and Expo \\ Austin, TX, USA. 11-13 June 2015
}

\begin{abstract}
Background
Participants in organized running commonly experience muscle and joint pain while training for and competing in distance events. Many runners report pain as a major influence on changes or breaks in training regimens, and as a common deterrent for returning to exercise after a break. Methylsulfonylmethane (MSM) is a sulfurbased nutritional supplement shown through several clinical trials to be effective in reducing pain associated with osteoarthritis, and to exhibit anti-inflammatory properties. To further investigate the role of MSM in pain management, this randomized, double-blind, placebo-controlled study evaluated the effects of MSM supplementation on exercise-induced muscle and joint pain.
\end{abstract}

\section{Methods}

Twenty-two healthy females $(\mathrm{n}=17)$ and males $(\mathrm{n}=5)$ (33.7 \pm 6.9 yrs.) were recruited from the 2014 Portland Half-Marathon registrant pool. Participants were randomized to take either MSM $\left(\right.$ OptiMSM $\left.^{\circledR}\right)(n=11)$, or a placebo $(\mathrm{n}=11)$ at $3 \mathrm{~g} /$ day for 21 days prior to the race and two days after (23 total). Pain was recorded using a $100 \mathrm{~mm}$ Visual Analogue Scale (VAS) for both muscle pain (MP) and joint pain (JP) on a single questionnaire. Participants completed the questionnaire at five time points. Baseline levels $\left(T_{0}\right)$ were recorded approximately one month prior to the race. Post-race pain levels were recorded at 15 minutes $\left(T_{1}\right), 90$ minutes $\left(T_{2}\right), 1$ Day $\left(\mathrm{T}_{3}\right)$, and 2 days $\left(\mathrm{T}_{4}\right)$ after race finish. Data were analyzed using linear mixed models controlled for baseline, with time point as a repeated factor. Simple contrasts compared post-race time points to baseline, and Student's t-tests assessed between-group time point comparisons.

\footnotetext{
* Correspondence: eric.withee@student.ncnm.edu

Helfgott Research Institute, National College of Natural Medicine, Portland, OR 97201, USA
}

\section{Results}

Half-marathon completion resulted in significant time effects for increased pain in both MP $(\mathrm{p}<0.001)$ and JP $(\mathrm{p}<0.001)$. Mean MP at $\mathrm{T}_{0}(14.7 \mathrm{~mm})$ significantly increased at $\mathrm{T}_{1}(38.4 \mathrm{~mm} ; \mathrm{p}<0.001), \mathrm{T}_{2}(33.5 \mathrm{~mm} ; \mathrm{p}=$ $0.001)$, and $\mathrm{T}_{3}(36.3 \mathrm{~mm} ; \mathrm{p}=0.001)$, and fell to non-significevels at $\mathrm{T}_{4}(20.9 \mathrm{~mm} ; \mathrm{p}=0.330)$. Mean JP at $\mathrm{T}_{0}$ $(8.4 \mathrm{~mm})$ significantly increased at $\mathrm{T}_{1}(33.5 \mathrm{~mm} ; \mathrm{p}<0.001)$, $\mathrm{T}_{2}(31.5 \mathrm{~mm} ; \mathrm{p}<0.001)$, and $\mathrm{T}_{3}(24.8 \mathrm{~mm} ; \mathrm{p}=0.004)$, and fell to non-significant levels at $\mathrm{T}_{4}(16.1 \mathrm{~mm} ; \mathrm{p}=0.198)$. The results showed a trend of lower pain levels in the MSM group. However, time-by-treatment effects did not reach significance in either MP or JP. Compared to placebo, MSM supplementation resulted in nearly significantly lower $\mathrm{MP}$ at $\mathrm{T}_{1}(\mathrm{MSM}=27.3 \mathrm{~mm}$ vs. placebo $=$ $49.8 \mathrm{~mm}, \mathrm{p}=0.063)$, and lower MP at $\mathrm{T}_{2}(27.1 \mathrm{~mm}$ vs. $40.0 \mathrm{~mm} ; \mathrm{p}=0.300)$, and $\mathrm{T}_{3}(30.0 \mathrm{~mm}$ vs. $41.9 \mathrm{~mm} ; \mathrm{p}=$ 0.306). Similar results were seen for JP at $T_{1}(24.2 \mathrm{~mm}$ vs. $42.4 \mathrm{~mm} ; \mathrm{p}=0.156), \mathrm{T}_{2}(22.7 \mathrm{~mm}$ vs $39.3 \mathrm{~mm} ; \mathrm{p}=0.204)$, and $\mathrm{T}_{3}(15.4 \mathrm{~mm}$ vs. $32.2 \mathrm{~mm} ; \mathrm{p}=0.152)$.

\section{Conclusion}

Exercise-induced muscle pain and joint pain increase within 15 minutes of completing a half-marathon, continue through the following day, and diminish approximately two days post-race. Three weeks of MSM supplementation at $3 \mathrm{~g} /$ day attenuated post-exercise muscle and joint pain at clinically significant levels compared to placebo. However, the pain reductions did not reach statistical significance, warranting further research on MSM and post-exercise pain among larger samples.

\section{Acknowledgements \\ Eric D Withee is employed part-time at Bergstrom Nutrition (Vancouver, WA), manufacturers of MSM (OptiMSMTM).}

Published: 21 September 2015 
doi:10.1186/1550-2783-12-S1-P8

Cite this article as: Withee et al: Effects of MSM on exercise-induced

muscle and joint pain: a pilot study. Journal of the International Society of Sports Nutrition 2015 12(Suppl 1):P8.

Submit your next manuscript to BioMed Central and take full advantage of:

- Convenient online submission

- Thorough peer review

- No space constraints or color figure charges

- Immediate publication on acceptance

- Inclusion in PubMed, CAS, Scopus and Google Scholar

- Research which is freely available for redistribution 